\title{
ZNF652 wt Allele
}

National Cancer Institute

\section{Source}

National Cancer Institute. ZNF652 wt Allele. NCI Thesaurus. Code C99597.

Human ZNF652 wild-type allele is located in the vicinity of 17q21.32 and is approximately $73 \mathrm{~kb}$ in length. This allele, which encodes zinc finger protein 652 , may be involved in both DNA binding and transcriptional repression. 